\title{
The production of calcium and magnesium during pancreatic function tests in health and disease
}

\author{
J. NIMMO, N. D. C. FINLAYSON, A. F. SMITH, AND D. J. C. SHEARMAN \\ From the Gastrointestinal Unit of the University Department of Therapeutics and the Royal Infirmary, \\ and the Department of Clinical Chemistry of the Royal Infirmary, Edinburgh
}

SUMMARY Duodenal calcium and magnesium concentrations after pancreatic stimulation were measured in 25 patients with and without pancreatic disease. The concentration of both ions was higher in those with pancreatic disease, and furthermore these patients showed a different secretory pattern. These findings may be relevant to the aetiology of pancreatitis and to pancreatic calcification, and might be of diagnostic value.

Pancreatic calcification is often seen in chronic pancreatitis and it is accepted that the pancreatic inflammatory disorders can be associated with abnormalities of calcium metabolism. For example between 7 and $19 \%$ of patients with hyperparathyroidism have had pancreatitis (Mixter, Keynes, and Cope, 1962; Ludwig and Chaykin, 1966).

The secretion of calcium into the duodenum in man has been studied by Hansky (1967) and from naturally occurring pancreatic fistulae by Kogut, Matzner, and Sobel (1936) and Sinclair (1956). Hansky (1967) reported an increased concentration of calcium in both the basal and the secretin-stimulated pancreatic juice in chronic pancreatitis although the total calcium output after stimulation was normal. There have been no previous studies on magnesium secretion by the pancreas. This paper reports the secretory pattern of these ions in pancreatic juice.

\section{Subjects and Methods}

PANCREATIC FUNCTION TEST

The duodenum was intubated under radiological control using a Dreiling double-lumen tube after the patient had fasted for 12 hours. Duodenal and gastric aspirates were then collected separately for a basal period of 1 hour during which it was ensured that the former was alkaline. The pancreas was then stimulated with an intravenous injection of secretin (Boots) in a dose of 3 units/ kg body weight. Aspiration was continued for a further hour, during which the duodenal juice was collected on ice and placed in sealed flasks in six ten minute-samples. At the end of the test, a plain $x$-ray of the abdomen was taken to ensure that the Dreiling tube had remained in the correct position. All gastric aspirate was discarded, and all duodenal aspirate kept for analysis.

The volume of the basal and the six samples taken after secretin stimulation was measured. Each sample was analysed for bicarbonate concentration by the Technicon AutoAnalyzer, for trypsin concentration by a kinetic method using benzoyl arginine ethyl ester as substrate and for calcium and magnesium concentration by the Perkin-Elmer (model 303), atomic absorption spectrophotometer (MacDonald and Watson, 1966).

Each test was classified as normal or abnormal on the basis of the volume of aspirate after secretin stimulation (normal-greater than 1.5 $\mathrm{ml} / \mathrm{kg}$ ), the maximum bicarbonate concentration (normal-greater than $75 \mathrm{~m}$-equiv/l) and the maximum trypsin concentration (normal-greater than 200 units/millitre). These values are based 


\begin{tabular}{|c|c|c|c|c|c|c|c|c|}
\hline $\begin{array}{l}\text { Patient } \\
\text { Number }\end{array}$ & Diagnosis & $\begin{array}{l}\text { Volume } \\
(\mathrm{ml} / \mathrm{kg} / \mathrm{hr})\end{array}$ & $\begin{array}{l}\text { Maximum } \\
\mathrm{HCO}_{3} \text { Con- } \\
\text { centration } \\
\text { (m-equiv/l) }\end{array}$ & $\begin{array}{l}\text { Maximum } \\
\text { Trypsin } \\
\text { Concentra- } \\
\text { tion } \\
\text { (units } / m l)\end{array}$ & $\begin{array}{l}\text { Calcium } \\
\text { Concentra- } \\
\text { tion } \\
(\mathrm{mg} / 100 \mathrm{ml})\end{array}$ & $\begin{array}{l}\text { Total } \\
\text { Calcium } \\
\text { Secreted } \\
(m g)\end{array}$ & $\begin{array}{l}\text { Magnesium } \\
\text { Concentra- } \\
\text { tion } \\
(\mathrm{mg} / 100 \mathrm{ml})\end{array}$ & $\begin{array}{l}\text { Total } \\
\text { Magnesium } \\
\text { Secreted } \\
(\mathrm{mg})\end{array}$ \\
\hline 1 & Normal & $2 \cdot 1$ & 123 & 590 & $1 \cdot 5$ & $1 \cdot 8$ & 0.2 & 0.2 \\
\hline 2 & Normal & 3.8 & 126 & 970 & $1 \cdot 5$ & $4 \cdot 2$ & 0.5 & $1 \cdot 4$ \\
\hline 3 & Normal & $1 \cdot 7$ & 99 & 380 & $1 \cdot 3$ & $1 \cdot \overline{3}$ & 0.3 & 0.3 \\
\hline 4 & Duodenal ulcer & $2 \cdot 8$ & 90 & 350 & $1 \cdot 6$ & $3 \cdot 3$ & 0.4 & 0.8 \\
\hline 5 & Duodenal ulcer & $3 \cdot 0$ & 84 & 930 & 0.9 & $1 \cdot 6$ & 0.2 & $0 \cdot 4$ \\
\hline 6 & Duodenal ulcer & $1 \cdot 8$ & 90 & Not done & $1 \cdot 8$ & $2 \cdot 1$ & 0.6 & $0 \cdot 7$ \\
\hline 7 & Coeliac disease & $5 \cdot 3$ & 114 & 600 & $1 \cdot 4$ & $3 \cdot 6$ & $0 \cdot 3$ & $0 \cdot 8$ \\
\hline 8 & Klinefelter's syndrome & $2 \cdot 8$ & 120 & 810 & $1 \cdot 6$ & $2 \cdot 9$ & 0.6 & $1 \cdot 0$ \\
\hline 9 & Weight loss & $4 \cdot 8$ & 90 & Not done & $4 \cdot 4$ & $10 \cdot 2$ & $1 \cdot 0$ & $2 \cdot 3$ \\
\hline 10 & Epigastric pain & $3 \cdot 7$ & 108 & 770 & $1 \cdot 8$ & $4 \cdot 2$ & 0.5 & $1 \cdot 2$ \\
\hline 11 & Epigastric pain & $2 \cdot 2$ & 102 & 340 & $1 \cdot 1$ & $1 \cdot \overline{7}$ & 0.7 & 0.7 \\
\hline 12 & Epigastric pain & $1 \cdot 5$ & 117 & 400 & $1 \cdot 4$ & $1 \cdot 2$ & 0.3 & 0.3 \\
\hline 13 & Epigastric pain & $1 \cdot 8$ & 120 & 480 & $1 \cdot 2$ & $1 \cdot 6$ & 0.4 & 0.5 \\
\hline 14 & Epigastric pain & $2 \cdot 2$ & 114 & 538 & 0.8 & $1 \cdot 2$ & $0 \cdot 3$ & 0.5 \\
\hline 15 & Epigastric pain & $3 \cdot 1$ & 108 & 320 & $1 \cdot 7$ & $2 \cdot 9$ & $0 \cdot 7$ & $1 \cdot 2$ \\
\hline 16 & Epigastric pain & $2 \cdot 4$ & 102 & Not done & $3 \cdot 2$ & $2 \cdot 5$ & 0.9 & $1 \cdot 4$ \\
\hline 17 & Chronic renal failure & $2 \cdot 9$ & 117 & 800 & 1.4 & $2 \cdot 6$ & 0.5 & 0.9 \\
\hline
\end{tabular}

Table I Patients without pancreatic disease

\begin{tabular}{|c|c|c|c|c|c|c|c|c|}
\hline $\begin{array}{l}\text { Patient } \\
\text { Number }\end{array}$ & Diagnosis & $\begin{array}{l}\text { Volume } \\
(\mathrm{ml} / \mathrm{kg} / \mathrm{hr})\end{array}$ & $\begin{array}{l}\text { Maximum } \\
\mathrm{HCO}_{3} \text { Con- } \\
\text { centration } \\
(m \text {-equiv/l) }\end{array}$ & $\begin{array}{l}\text { Maximum } \\
\text { Trypsin } \\
\text { Con- } \\
\text { centration } \\
\text { (units } / \mathrm{ml})\end{array}$ & $\begin{array}{l}\text { Calcium } \\
\text { Concentra- } \\
\text { tion } \\
(\mathrm{mg} / 100 \mathrm{ml})\end{array}$ & $\begin{array}{l}\text { Total } \\
\text { Calcium } \\
\text { Secreted } \\
(\mathrm{mg})\end{array}$ & $\begin{array}{l}\text { Magnesium } \\
\text { Concentra- } \\
\text { tion } \\
(\mathrm{mg} / 100 \mathrm{ml})\end{array}$ & $\begin{array}{l}\text { Total } \\
\text { Magnesium } \\
\text { Secreted } \\
(\mathrm{mg})\end{array}$ \\
\hline 18 & Relapsing pancreatitis & $1 \cdot 7$ & 75 & 600 & $2 \cdot 1$ & 2.9 & 0.7 & $1 \cdot 0$ \\
\hline 19 & Relapsing pancreatitis & 0.8 & 15 & 30 & $4 \cdot 2$ & $1 \cdot 5$ & $1 \cdot 2$ & 0.4 \\
\hline 20 & Relapsing pancreatitis & $1 \cdot 0$ & 69 & 710 & $4 \cdot 0$ & $2 \cdot 7$ & $1 \cdot 2$ & 0.8 \\
\hline 21 & Chronic pancreatitis & $1 \cdot 0$ & 33 & 30 & $3 \cdot 1$ & $2 \cdot 0$ & 0.9 & 0.5 \\
\hline 22 & Chronic pancreatitis & $0 \cdot 3$ & 48 & 650 & $2 \cdot 3$ & 0.6 & 0.9 & $0 \cdot 2$ \\
\hline 23 & Chronic pancreatitis & $1 \cdot 3$ & 15 & 65 & $2 \cdot 7$ & $2 \cdot 2$ & $0 \cdot 7$ & $0 \cdot 6$ \\
\hline 24 & Chronic pancreatitis & 1.0 & 27 & 120 & $2 \cdot 5$ & $3 \cdot 8$ & $1 \cdot 7$ & $1 \cdot 3$ \\
\hline 25 & Cancer of pancreas & $1 \cdot 0$ & 30 & 20 & $12 \cdot 0$ & 7.9 & $2 \cdot 3$ & $1 \cdot 5$ \\
\hline
\end{tabular}

Table II Patients with pancreatic disease

on a series of normal patients tested by us under the above conditions.

\section{SUBJECTS}

Twenty-five subjects were studied. Three were volunteers without gastrointestinal symptoms, three had radiologically proven duodenal ulceration, one had coeliac disease, one had Klinefelter's syndrome with recent weight loss, one had weight loss of unknown origin, one had chronic renal failure with episodic epigastric pain, and seven had epigastric pain of unknown cause with no clinical evidence of pancreatitis and normal pancreatic function tests. All these patients had normal test results. Eight patients had pancreatic disease. Of these, three had relapsing pancreatitis, two with grossly abnormal test results and one with borderline values, four had chronic pancreatitis with exocrine and endocrine pancreatic failure, and one had carcinoma of the pancreas. In case 18 the pancreatic function test results were just normal but this patient was included in the group with pancreatic disease because of relapsing pancreatitis as proved by greatly raised serum amylase levels during relapses.

\section{Results}

Tables I and II show the diagnosis and the results of duodenal juice analysis in the hour after secretin stimulation in patients with and without pancreatic disease.

Table III shows the mean concentrations and the total production of calcium and magnesium 


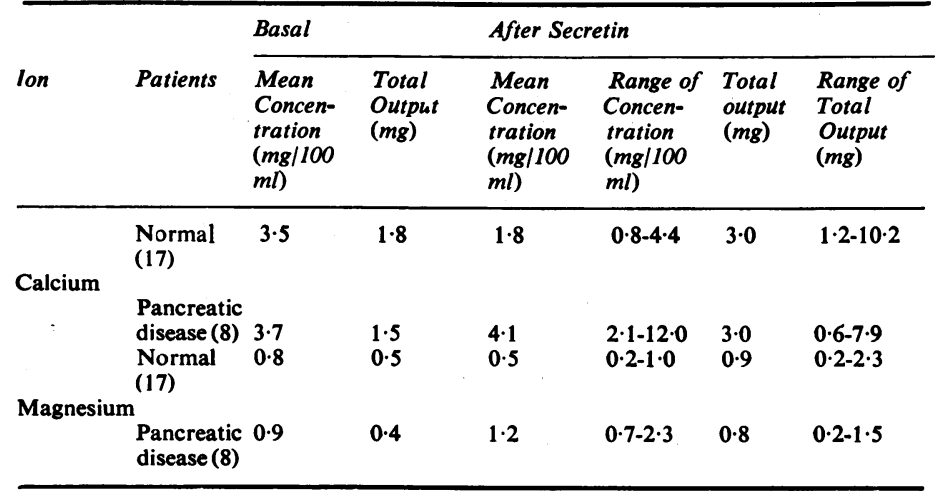

Table III Concentration and total production of calcium and magnesium before and after secretin

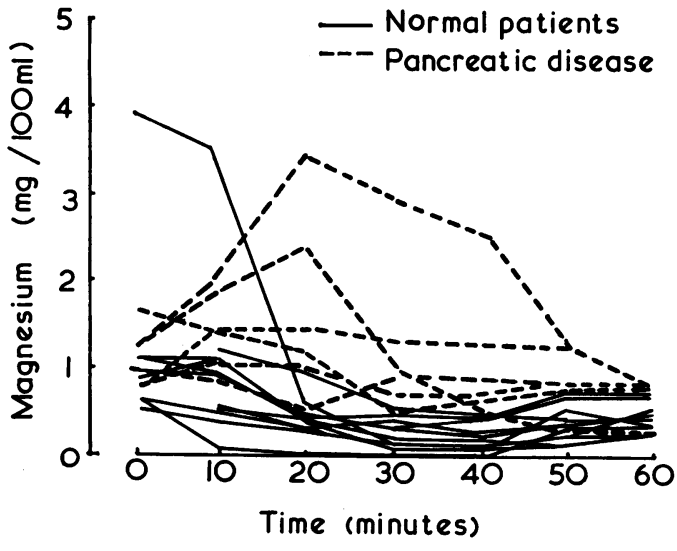

Fig. 2 Magnesium concentration in post-secretin hour.

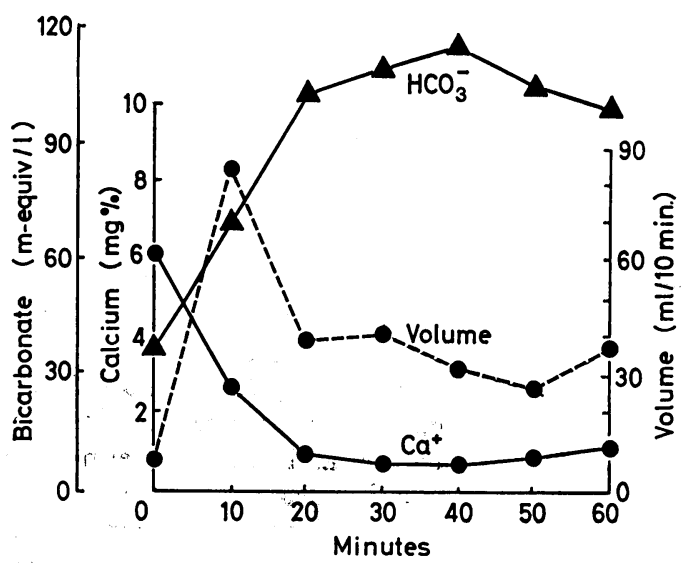

Fig. 3 Bicarbonate and calcium concentrations in the hour after, secretin.

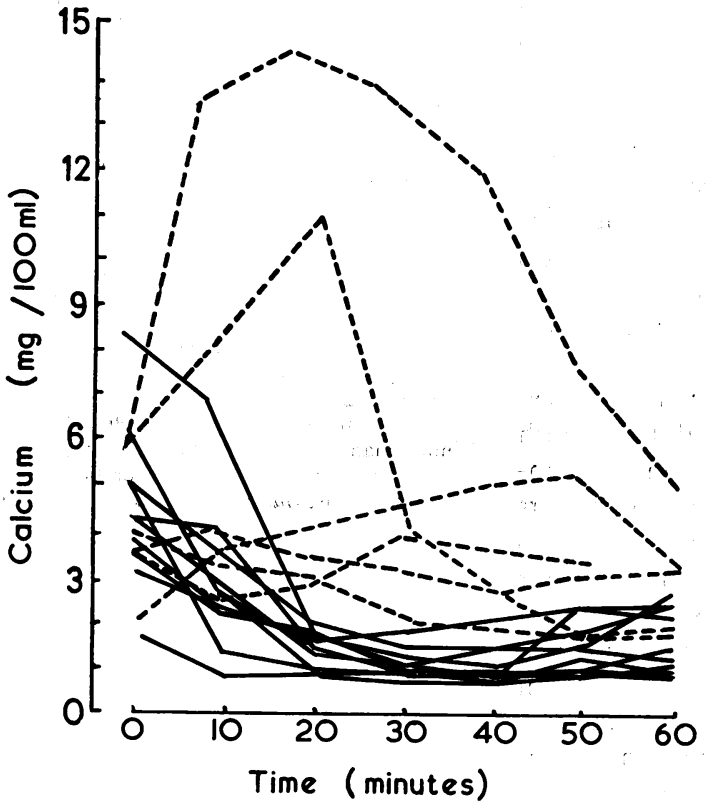

- Normal patients

--- Pancreatic disease

\section{Fig. 1 Calcium concentration in post-secretin hour.}

in the basal and in the post-secretin hour in patients with and without pancreatic disease. The only statistically significant difference between the two groups of patients was the higher mean concentration of calcium and magnesium in the group with pancreatic disease after secretin stimulation.

Figures 1 and 2 show the patterns of secretion for calcium and magnesium in both normal and abnormal patients. Each value represents the concentration of the ion in $\mathrm{mg} / 100 \mathrm{ml}$ during successive 10 minute collection periods following intravenous secretin given at time zero.

In all patients without pancreatic disease there was an inverse relationship between bicarbonate concentration and calcium concentration as 
illustrated by one patient in Figure 3. The same relationship existed for magnesium.

An analysis of the calcium/magnesium ratios was made on all samples. There was no difference between those with and without pancreatic disease.

\section{Discussion}

In persons without pancreatic disease secretin stimulation caused an increase in the volume of duodenal aspirate and in bicarbonate concentration with a reciprocal fall in calcium and magnesium concentration. This agrees with the work on calcium by Herskovic, Wakim, Bartholomew, Cain, and Jones (1965), and by Zimmerman, Dreiling, Rosenberg, and Janowitz (1967) in the dog. In the patients with chronic pancreatitis described here the volume of duodenal aspirate rises to a much smaller extent after stimulation than in patients without pancreatic disease and the calcium and magnesium concentration also rises. However, the total amount of calcium and magnesium secreted is the same in the two groups, so that the difference in the calcium and magnesium concentration can possibly be attributed to the differences in the amount of juice secreted. Our results do not support the findings of Hansky (1967), who found no relationship between bicarbonate and calcium concentrations in normal persons.

Hansky (1967) reported significantly raised calcium concentrations in duodenal fluid both before and after secretin stimulation in pancreatic disease, and he noted that the two patients in his series who had pancreatic calcification also had the highest calcium concentrations. In our study, patients with chronic pancreatitis did not have a significantly raised basal calcium concentration, but it was noted that our only patient (case 25) with pancreatic calcification had the highest post-secretin calcium concentrations (mean $12 \mathrm{mg} / 100 \mathrm{ml}$ : maximum $14.5 \mathrm{mg} / 100 \mathrm{ml}$ ) and the highest total calcium output $(7.9 \mathrm{mg})$ in his group although his serum calcium level $(8.3 \mathrm{mg} / 100 \mathrm{ml})$ was low. This patient had pancreatic carcinoma with calcification but it is not known if chronic pancreatitis existed before the development of the carcinoma. Conversely, $\stackrel{?}{\rightarrow}$ one patient (case 9) with normal pancreatic function had even higher concentrations ando total output of calcium after secretin, and had a을 serum calcium level of $12.3 \mathrm{mg} / 100 \mathrm{ml}$. Although $\frac{\bar{\rho}}{\triangle}$

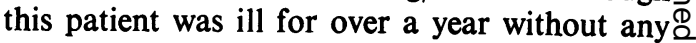
cause being found for the raised serum calcium level he did not develop pancreatic calcification. $\overrightarrow{0}$ It was notable that this patient produced twice $\stackrel{-}{-}$ as much basal volume and four times as much $\vec{\omega}$ stimulated volume as the patient with chronic $\stackrel{\odot}{\varrho}$ calcific pancreatitis. It may be then that the reduced volume of secretion in chronic pancrea- $\overrightarrow{-}$ titis is an additional factor in allowing calcifi- $\bar{i}$ cation to occur.

We thank the Medical Research Council for a grant $\stackrel{\circ}{\supset}$ for technical assistance for this work.

References

Hansky, J. (1967). Calcium content of duodenal juice. Amer. J. dig. Dis., 12, 725-733.

Herskovic, T., Wakim, K. G., Bartholomew, L. G., Cain, J. C., and Jones, J. D. (1965). Relationship of calcium in the $\vec{\theta}$ serum to that in the pancreatic secretion in normal and hypercalcemic states. Surgery, 58, 530-534.

Kogut, B., Metzner, M. J., and Sobel, A. E. (1936). A study of external pancreatic secretion in man. J. clin. Invest., 15, 393-396.

Ludwig, G. D., and Chaykin, L. B. (1966). Pancreatitis associated with primary hyperparathyroidism. Med. Clin. N. Amer., 50, 1403-1418.

Mixter, C. G., Jr., Keynes, W. M., and Cope, O. (1962). Further experience with pancreatitis as a diagnostic clue to hyper- $\overrightarrow{\vec{O}}$ parathyroidism. New Engl. J. Med., 266, 265-272.

MacDonald, M. A., and Watson, L. (1966). The determination of magnesium in biological materials by atomic absorption spectrophotometry. Clin. chim. acta, 14, 233-241.

Sinclair, I. S. R. (1956). Observations on a case of external pancreatic fistula in man. Brit. J. Surg., 44, 250-262.

Zimmerman, M. J., Dreiling, D. A., Rosenberg, I. R., and Janowitz, H. D. (1967). Secretion of calcium by the canine pancreas. Gastroenteralogy, 52, 865-870. 